\title{
PENGARUH PARTISIPASI MASYARAKAT, PENGGUNAAN SISTEM KEUANGAN DESA, KOMPETENSI PENDAMPING DESA SERTA KOMITMEN PEMERINTAH DAERAH TERHADAP KEBERHASILAN PENGELOLAAN DANA DESA
}

\author{
I Putu Julianto ${ }^{a^{*}}$, Gusti Ayu Ketut Rencana Sari Dewi ${ }^{\mathrm{b}}$ \\ a,bUniversitas Pendidikan Ganesha, Jalan Udayana No. 11, Singaraja, \\ Bali, Indonesia \\ *(putujulianto@undiksha.ac.id)
}

\begin{abstract}
ABSTRAK
Penelitian ini bertujuan untuk mengetahui pengaruh partisipasi masyarakat, penggunaan sistem keuangan desa, kompetensi pendamping desa, komitmen pemerintah daerah terhadap keberhasilan pengelolaan dana desa. Penelitian ini merupakan penelitian kuantitatif dengan menggunakan jenis data primer yang diperoleh dari kuesioner dan diukur dengan menggunakan skala likert. Populasi pada penelitian ini menggunakan seluruh kepala desa, bendahara desa, sekretaris desa, serta operator siskeudes di Kabupaten Buleleng. Teknik pengambilan sampel menggunakan probability sampling yaitu simple random sampling. Kriteria sampel dalam penelitian ini adalah kepala desa, sekretaris desa, bendahara desa, dan operator siskeudes di Kabupaten Buleleng sebanyak 224 orang. Teknik analisis data dalam penelitian ini menggunakan analisis regresi linier berganda dengan bantuan SPSS versi 23. Hasil dari penelitian ini menunjukkan bahwa variabel partisipasi masyarakat $\left(\mathrm{X}_{1}\right)$ berpengaruh secara positif dan signifikan terhadap keberhasilan pengelolaan dana desa, variabel penggunaan sistem keuangan desa $\left(\mathrm{X}_{2}\right)$ berpengaruh secara positif dan signifikan terhadap keberhasilan pengelolaan dana desa, variabel kompetensi pendamping desa $\left(\mathrm{X}_{3}\right)$ berpengaruh secara positif dan signifikan terhadap keberhasilan pengelolaan dana desa, serta variabel komitmen pemerintah daerah $\left(\mathrm{X}_{4}\right)$ berpengaruh secara positif dan signifikan terhadap keberhasilan pengelolaan dana desa.

Kata kunci: Keberhasilan Pengelolaan Dana Desa, Komitmen Pemerintah Daerah, Kompetensi Pendamping Desa, Partisipasi Masyarakat, Penggunaan Siskeudes

ABSTRACT

Research aims to understand The Influence of Public Participation, The Use of the Villages Financial System, A Companion Competence of the Villages and Local Government Commitment to Successful of Village Funds Management. The research is quantitative research using types of data on obtained from the questionnaire and primary is measured using likert scales. The population in this study using the whole chief of village officer, treasurer, thevillages officials, as well as the operator siskeudes in Buleleng Regency. The sample collection
\end{abstract}


technique use probability sampling that is simple random sampling. The criteria of the samplein this study isthe whole chief of village officer, treasurer, the villages officials, as well as the operator siskeudes in BulelengRegency as many as 224 people.Data analysis techniques in this study using multiple linear regression analysis with SPSS version 23. The results of the research indicated that the variable public participation ( $x 1$ ) influence positively and significant to successful of village funds management, the use of the village financial system (x2) influence positively and significant to successful of village funds management, variable a companion competence of the villages (x3) influence positively and significant to successful of village funds management, and the variable of local government commitment $(x 4)$ influence positively and significant to successful of village funds management.

Keywords: successful of village funds management, local government commitment, companion competence of the villages, public participation, siskeudes use

\section{PENDAHULUAN}

\begin{tabular}{lrr}
\multicolumn{2}{c}{ Undang-undang desa } & telah \\
menempatkan desa sebagai ujung & ujan \\
tombak & pembangunan & dan \\
peningkatan & kesejahteraan \\
masyarakat. & Desa & diberikan \\
kewenangan dan sumber dana yang \\
memadai agar dapat mengelola \\
potensi yang dimilikinya guna \\
meningkatkan & ekonomi dan
\end{tabular}

kesejahtaraan masyarakat. Setiap tahun pemerintah pusat telah menganggarkan dana desa yang cukup besar untuk diberikan kepada desa. Program dana desa yang gelontorkan oleh pemerintah pusat pada 2015 lalu sangat berdampak besar pada pengentasan desa tertinggal menjadi berkembang dan desa berkembang menjadi desa mandiri.

Salah satunya di provinsi Bali, yang penanganan desa tertinggalnya sudah tuntas atau tidak ada lagi desa tertinggal di Bali. Provinsi Bali sendiri merupakan salah satu dari 34 provinsi yang ada di Indonesia yang menerima alokasi dana desa dari pemerintah pusat. Kabupaten Buleleng merupakan salah satu Kabupaten yang berada di Provinisi Bali yang memperoleh alokasi dana desa dari pemerintah pusat yang berasal dari APBN. Data statistik menunjukkan bahwa alokasi dana desa yang diperoleh Kabupaten Buleleng mengalami peningkatan setiap tahunnya.

Namun bertambahnya alokasi dana desa tiap tahunnya tidak menjamin teresapnya seluruh dana desa yang diperoleh. Seperti yang terjadi pada tahun 2017, realisasi penggunaan dana desa di Kabupaten Buleleng hanya sebesar 51,92\% terhadap alokasi dana desa. Kasus lain yang terjadi di Kabupaten Buleleng pada tahun 2018 ini yaitu masih rendahnya realisasi 
penyerapan dana desa yang terjadi di beberapa desa.

Penelitian ini bertujuan untuk mengetahui bagaimana pengaruh partisipasi masyarakat, penggunaan sistem keuangan desa, kompetensi pendamping desa, komitmen pemerintah daerah terhadap keberhasilan pengelolaan dana desa. Menurut Mulyanto (2015) dalam Saputra (2018), besarnya alokasi dana desa yang dianggarkan pemerintah pusat membuat sejumlah desa harus melakukan profesionalisme pengelolaan dengan manajemen tata kelola keuangan desa yang mumpuni. Dengan adanya UU Nomor 6 Tahun 2014 tentang Desa, maka banyak harapan yang muncul baik dari pemerintah ataupun masyarakat. Masyarakat desa yang sejahtera, pemerintahan desa yang kuat dan kualitas hidup masyarakat desa yang layak menjadi harapan tertinggi. Besarnya harapan tersebut membuat desa harus melakukan tata kelola dana desa dengan baik, pembenahan pun perlu dilakukan seperti misalnya, perbaikan sumber daya manusia, komitmen pemerintah desa terhadap pembangunan, dan lain-lain.

Penelitian ini disusun dengan sistematika sebagai berikut. Bagian selanjutnya menjabarkan telaah literatur dan perumusan hipotesis yang diuji. Bagian berikutnya menjelaskan metode penelitian yang digunakan, pembahasan atas hasilhasil penelitian serta ditutup oleh bagian kesimpulan dan saran.

\section{TELAAH LITERATUR DAN PERUMUSAN HIPOTESIS Hubungan antara
Masyarakat $\begin{gathered}\text { Partisipasi } \\ \text { dan }\end{gathered}$
Keberhasilan}

Dalam penelitian yang dilakukan Lomboh (2015), menunjukkan bahwa partisipasi masyarakat sangat dibutuhkan untuk keberhasilan pembangunan di desa menuju kearah yang lebih baik, peran dan kinerja pemerintahan desa juga sangat diharapkan untuk dapat menjalankan tugas pokok memimpin dan mengkoordinasikan dalam melaksanakan urusan rumah tangga desa, melakukan pembinaan dan pembangunan masyarakat dan membina perekonomian desa. Seperti yang dikatakan oleh Sekretaris Jenderal (Sekjen) Kementerian Desa, Pembangunan Daerah Tertinggal, dan Transmigrasi (Kemendes PDTT), Anwar Sanusi di nusakini.com tanggal 6 November 2017, bahwa pengelolaan dana desa dilakukan secara transparan dan bertanggungjawab. Pelibatan masyarakat dalam proses perencanaan, pelaksanaan, hingga pengawasan program-program 
pembangunan desa menjadi kunci keberhasilan pengelolaan dana desa.

Berdasarkan penjabaran di atas, maka diajukan hipotesis pertama sebagai berikut:

$$
\begin{array}{rlr}
\mathrm{H}_{1}: & \text { Partisipasi } & \text { masyarakat } \\
\text { berpengaruh } & \text { terhadap } \\
\text { keberhasilan } & \text { pengelolaan dana } \\
\text { desa } &
\end{array}
$$

\section{Hubungan antara Penggunaan Sistem Keuangan Desa dan Keberhasilan Pengelolaan Dana Desa}

Pemberian dana ke desa yang begitu besar, jumlah pelaporan yang beragam dalam pengelolaan keuangan desa tentunya menuntut tanggung jawab yang besar pula oleh aparat pemerintah desa. Oleh karena itu pemerintah desa harus bisa menerapkan prinsip akuntabilitas dalam pengelolaan keuangan desa, dimana semua akhir kegiatan penyelenggaraan pemerintahan desa harus dapat dipertanggungjawabkan kepada masyarakat desa sesuai dengan ketentuan sehingga terwujud tata kelola pemerintahan desa yang baik (Good Village Governance). Untuk dapat menerapkan prinsip akuntabilitas tersebut, diperlukan berbagai sumber daya dan sarana pendukung, diantaranya sumber daya manusia yang kompeten serta dukungan sarana teknologi informasi yang memadai dan dapat diandalkan. Pengelolaan alokasi dana desa harus diawasi dengan baik agar pengelolaan dana desa ini berjalan secara efektif, efisien, dan ekonomis.

Salah satunya dengan cara menerapkan penggunaan Sistem Keuangan Desa dalam pengelolaan keuangan desa. Aplikasi Sistem Keuangan Desa (Siskeudes) merupakan aplikasi yang dikembangkan Badan Pengawasan Keuangan dan Pembangunan (BPKP) dalam rangka meningkatkan kualitas tata kelola keuangan desa. Sistem Keuangan Desa (Siskeudes) sangat diperlukan dalam pengelolaan keuangan pemerintahan desa. Keberadaannya membantu agar semua proses pembangunan, mulai dari perencanaan, pelaksanaan hingga evaluasi bisa dilaksanakan dengan baik.

Dengan adanya siskeudes ini akan membantu pengelolaan keuangan dana desa secara transparan dan akuntabel, dengan penggunaan sistem keuangan desa yang baik akan mempermudah dan mempercepat dalam hal pencairan dana desa untuk periode selanjutnya karena sudah melaporkan realisasi periode sebelumnya secara tepat waktu. Dengan begitu sistem keuangan desa sangat berperan 
penting dalam hal keberhasilan pengelolaan dana desa.

Berdasarkan penjabaran di atas, maka diajukan hipotesis kedua sebagai berikut:

$\mathrm{H}_{2}$ : Penggunaan sistem keuangan desa berpengaruh terhadap keberhasilan pengelolaan dana desa

\section{Hubungan antara Kompetensi Pendamping Desa dan Keberhasilan Pengelolaan Dana Desa}

Walaupun pengelolaan keuangan di desa sudah diawasi dengan adanya Siskeudes, tetap saja peran pendamping desa diperlukan dalam pengawasan penggunaan dana desa. Dalam implementasi UU desa, pendamping desa sangat dibutuhkan untuk mendampingi dan membina perangkat desa dalam segala pekerjaan teknis yang ada di desa. Kompetensi seorang pendamping desa sangat mendukung keberhasilan pengelolaan dana desa.

Hasil penelitian Pratama (2017) menunjukkan bahwa kinerja pendamping desa dengan melakukan pendekatan-pendekatan social seperti lebih sering berkomunikasi dengan desa dan masyarakatnya serta bertatap muka langsung sehingga akan terjalin ikatan yang baik, dan lain sebagainya berpengaruh terhadap upaya membangun kemandirian desa. Pahlevi (2017) menyatakan bahwa pendamping desa memiliki pengaruh yang signifikan terhadap keberhasilan pengelolaan dana desa, pengaruh ini dapat dibuktikan dengan pernyataan bahwa banyaknya faktor penghambat dalam pelaksanaan kewenangan pendamping desa yaitu kurangnya partisipasi dari masyarakat desa, ketersediaan fasilitas yang belum memadai, dan kurangnya jumlah sumber daya manusia sebagai pendamping desa. Adapun hasil penelitian dari Gameliel (2015) menyatakan bahwa kompetensi dalam aparat pengelola dana desa berpengaruh positif dan signifikan terhadap akuntabilitas pengelolaan dana desa di Kabupaten Gorontalo. Artinya semakin kompeten aparat pengelola dana desa, maka pengelolaan dana desa semakin akuntabel.

Hasil penelitian dari Saputra, dkk (2018) menyatakan bahwa kompetensi pendamping desa memiliki pengaruh yang signifikan terhadap keberhasilan pengelolaan dana desa. Penelitian yang sama juga dilakukan oleh Parwati dkk (2017) yang menghasilkan pernyataan bahwa kompetensi pendamping desa berpengaruh 
positif dan signifikan terhadap keberhasilan pengelolaan dana desa.

Berdasarkan penjabaran di atas, maka diajukan hipotesis ketiga sebagai berikut:

$\mathrm{H}_{3}$ : Kompetensi pendamping desa berpengaruh terhadap keberhasilan pengelolaan dana desa

\section{Hubungan Pemerintah antara Komitmen Keberhasilan Desa}

Apabila pendampingan desa di suatu desa oleh pendamping desa tidak berjalan secara optimal, jalan lain yang ditempuh oleh desa yaitu dengan mengundang para praktisi dan akademisi untuk datang ke desanya memberikan penyuluhan, sosialisasi hingga pendampingan. Disamping itu, perangkat desa wajib mengikuti segala bentuk pelatihan yang dilaksanakan oleh pemerintah daerah sebagai wujud nyata kepedulian pemerintah daerah terhadap pengelolaan keuangan desa supaya tidak terlepas dari azas pengelolaan keuangan yang sesungguhnya yaitu akuntabel, transparan dan partisipatif. Wujud komitmen pemerintah daerah untuk ikut membantu pemerintah desa memecahkan segala permasalahan yang berkaitan dengan pengelolaan dana desa saat ini cukup signifikan.
Pemerintah daerah sangat peduli dengan kesuksesan pemerintah desa untuk mencapai tujuan dari desanya masing-masing. Bentuk kepedulian pemerintah daerah saat ini misalnya pemda mengadakan pelatihan tata kelola keuangan desa, memberikan pelatihan tentang penggunaan sistem informasi desa, memfasilitasi desa dalam semua bentuk kegiatan yang berhubungan dengan pengelolaan dana desa serta peningkatan pendapatan asli desa. Semua bentuk dukungan pemerintah daerah terhadap keberhasilan dana desa sangatlah nyata di berbagai bidang termasuk pengawasan dan pendampingan.

Semangat Undang-undang Desa merupakan wujud dari komitmen pemerintah mendorong otonomi desa. Wujud komitmen pemerintah daerah dalam pengelolaan dana desa dapat berupa pemberian pembinaan, pelatihan serta pengawasan dalam hal penggunaan dana desa supaya tepat sasaran. Seperti yang disampaikan oleh Wakil Presiden RI Jusuf Kalla di www. wapresri.go.id (2015) bahwa pemerintah pusat dan daerah berkomitmen mengembangkan otonomi daerah melalui pembangunan lingkup daerah terkecil pedesaan. Pernyataan lainnya disampaikan oleh Yujana (2017) bahwa komitmen pemerintah 
daerah dalam pengelolaan dana desa dibuktikan melalui pengawasan dalam bentuk Rancangan APBDes sebelum ditetapkan oleh Kepala Desa harus disupervisi dan dievaluasi. Untuk pengawasan dalam konteks audit, hingga saat ini belum ada regulasi yang mengatur. Namun, konvensi saat ini menyepakati audit dilakukan oleh inspektorat Kabupaten/Kota oleh Bupati melalui Camat.

Berdasarkan penjabaran di atas, maka diajukan hipotesis keempat sebagai berikut:

$\mathrm{H}_{4}$ : Komitmen pemerintah daerah berpengaruh terhadap keberhasilan pengelolaan dana desa

\section{METODE}

Penelitian ini merupakan penelitian kuantitatif yang dilakukan pada seluruh desa yang menerima dana desa di Kabupaten Buleleng. Populasi dalam penelitian ini berjumlah 129 desa yang terdapat di Kabupaten Buleleng. Selanjutnya teknik pengambilan sampel yang digunakan dalam penelitian ini yaitu menggunakan probability sampling yakni simple random sampling, dan juga dalam menentukan jumlah sampel yang digunakan, dilakukan perhitungan dengan menggunakan rumus Slovin agar diketahui sampel yang representatif dan hasil penelitian dapat digeneralisasikan sehingga diperoleh hasil sejumlah 56 sampel penelitian dengan 224 responden.

Data dalam penelitian ini dikumpulkan dengan menggunakan kuesioner yang kemudian diolah dengan menggunakan teknik analisis dataantara lain uji statistik yaitu uji statistik deskriptif, uji kualitas data yang digunakan adalah uji validitas dan reliabilitas, uji asumsi klasik terdiri dari uji normalitas, heterokedastisitas, multikolonearitas, analisis regresi linier berganda dan uji hipotesis yaitu uji koefisien determinasi, dan uji t.

\section{HASIL DAN PEMBAHASAN}

\section{Hasil}

Berdasarkan hasil uji statistik deskriptif dinyatakan bahwa variabel partisipasi masyarakat $\left(\mathrm{X}_{1}\right)$ mempunyai skor minimum 20, skor maksimum 35 , skor rata-rata 28,46 dengan standar deviasi 3,751. Hal ini menunjukkan bahwa terjadi perbedaan nilai partisipasi masyarakat terhadap nilai rata-rata sebesar 3,751.

Variabel penggunaan Siskeudes $\left(\mathrm{X}_{2}\right)$ mempunyai skor minimum 18 , skor maksimum 25, skor rata-rata 21,66 dengan standar deviasi 1,906. Hal ini menunjukkan bahwa terjadi 
perbedaan nilai penggunaan

Siskeudes terhadap nilai rata-rata sebesar 1,906 .

$$
\text { Variabel kompetensi }
$$

pendamping desa $\left(\mathrm{X}_{3}\right)$ mempunyai skor minimum 50, skor maksimum 70, skor rata-rata 61,77 dengan standar deviasi 5,561. Hal ini menunjukkan bahwa terjadi perbedaan nilai kompetensi pendamping desa terhadap nilai rata-rata sebesar 5,561 .

Variabel komitmen pemerintah daerah $\left(\mathrm{X}_{4}\right)$ mempunyai skor minimum 38, skor maksimum 50, skor rata-rata 45,05 dengan standar deviasi 3,654. Hal ini menunjukkan bahwa terjadi perbedaan nilai komitmen pemerintah daerah terhadap nilai rata-rata sebesar 3,654 .

Variabel keberhasilan pengelolaan dana desa $(\mathrm{Y})$ mempunyai skor minimum 42, skor maksimum 60, skor rata-rata 52,71 dengan standar deviasi 3,816. Hal ini menunjukkan bahwa terjadi perbedaan nilai keberhasilan pengelolaan dana desa terhadap nilai rata-rata sebesar 3,816 .

Tabel 1. Hasil Analisis Deskriptif Statistik

\begin{tabular}{lccccc}
\hline \multicolumn{7}{c}{ Descriptive Statistics } \\
& $N$ & Minimum & Maximum & Mean & $\begin{array}{c}\text { Std. } \\
\text { Deviation }\end{array}$ \\
& 224 & 20 & 35 & 28,46 & 3,751 \\
Partisipasi Masyarakat & 224 & 18 & 25 & 21,66 & 1,906 \\
Penggunaan Siskeudes & 224 & 50 & 70 & 61,77 & 5,561 \\
Kompetensi Pendamping Desa & 224 & 38 & 50 & 45,05 & 3,654 \\
Komitmen Pemerintah Daerah & 22 & 42 & 60 & 52,71 & 3,816 \\
Keberhasilan Pengelolaan Dana & 224 & 42 & & & \\
Desa & 224 & & & &
\end{tabular}

Sumber: Data Diolah, 2018

Selain uji statistik deskriptif dilakukan juga uji kualitas data yang terdiri dari uji validitas dan uji reliabilitas. Uji validitas dimaksudkan untuk menguji seberapa baik instrumen penelitian mengukur konsep yang seharusnya di ukur. Uji validitas dilakukan dengan menghitung korelasi antara skor masingmasing butir pernyataan dengan total skor sehingga didapat nilai Pearson Correlation. Berdasarkan uji validitas yang telah dilakukan dapat dilihat bahwa semua instrumen memiliki nilai pearson 
correlation lebih besar daripada 0,3 dan nilai Sig. (2-tailed) korelasi untuk semua item lebih kecil daripada 0,05 sehingga dapat disimpulkan seluruh item pernyataan dinyatakan valid.

Uji kualitas data selanjutnya byaitu uji reliabilitas. Reliabilitas adalah alat untuk mengukur suatu kuesioner yang merupakan statistik dari variabel atau konstruk. Kriteria yang digunakan adalah suatu konstruk atau variabel dikatakan reliable jika memberikan nilai Cronbach Alpha $>0,600$ (Ghozali, 2012).

Tabel 2. Hasil Uji Reliabilitas

\begin{tabular}{clcc}
\hline No. & \multicolumn{1}{c}{ Variabel } & Cronbach AlphaKeterangan \\
\hline 1 & Partisipasi Masyarakat & 0,824 & Reliabel \\
2 & Penggunaan Siskeudes & 0,794 & Reliabel \\
3 & Kompetensi Pendamping Desa & 0,931 & Reliabel \\
4 & Komitmen Pemerintah Daerah & 0,903 & Reliabel \\
5 & Keberhasilan Pengelolaan Dana Desa & 0,869 & Reliabel \\
\hline
\end{tabular}

Sumber: Data Diolah, 2018

Tabel 3. Hasil Uji Normalitas

\begin{tabular}{lr}
\hline & Unstandardized Residual \\
\hline Kolmogorov-Smirnov $Z$ & 0,113 \\
Asymp. Sig. (2-tailed) & 0,103 \\
\hline
\end{tabular}

Sumber: Data Diolah, 2018

Tabel 4. Hasil Uji Multikolinieritas

\begin{tabular}{lccl}
\hline \multirow{2}{*}{ Model } & \multicolumn{2}{c}{ Collinearity Statistics } & \multirow{2}{*}{ Keterangan } \\
\cline { 2 - 3 } & Tolerance & VIF & \\
\hline Partisipasi Masyarakat & 0,706 & 1,416 & Bebas Multikolinearitas \\
Penggunaan Siskeudes & 0,607 & 1,647 & Bebas Multikolinearitas \\
Kompetensi Pendamping Desa & 0,438 & 2,281 & Bebas Multikolinearitas \\
Komitmen Pemerintah Daerah & 0,432 & 2,313 & Bebas Multikolinearitas \\
\hline
\end{tabular}

Sumber: Data Diolah, 2018

Berdasarkan data pada tabel 2 dapat dilihat bahwa variabel partisipasi masyarakat mempunyai nilai Cronbach's Alpha sebesar 0,824. Variabel penggunaan Siskeudes mempunyai nilai Cronbach's Alpha sebesar 0,794. Variabel kompetensi pendamping desa mempunyai nilai Cronbach's Alpha sebesar 0,931. Variabel komitmen pemerintah daerah mempunyai nilai Cronbach's Alpha sebesar 0,903. Variabel keberhasilan pengelolaan dana desa mempunyai nilai Cronbach's Alpha 
sebesar 0,869. Semua variabel mempunyai nilai Cronbach'sAlpha lebih besar dari 0,60, sehingga dapat dinyatakan instrumen pada penelitian ini reliabel.

Sementara itu, berdasarkan data pada tabel 3, dapat dilihat bahwa nilai Kolmogorov Smirnov sebesar 0,113 dengan nilai signifikansi sebesar 0,103>0,05 yang berarti nilai residual berdistribusi secara normal. Hasil uji multikolinearitas juga menunjukkan bahwa semua variabel independen mempunyai nilai VIF lebih kecil daripada 10 dan nilai tolerance lebih besar 0,10, sehingga dapat disimpulkan bahwa model bebas dari multikolinearitas.

Berdasarkan hasil uji heterokedastisitas yang digunakan untuk menguji penyimpangan asumsi klasik heteroskedastisitas yaitu terjadi ketidaksamaan varians dari residual suatu pengamatan ke pengamatan lain pada model regresi. Untuk mendeteksi ada tidaknya heteroskedastisitas, dalam penelitian ini menggunakan Uji Glejser. Apabila nilai signifikansi > 0,05 maka terjadi homoskedastisitas dan ini yang seharusnya terjadi, namun jika sebaliknya nilai signifikansi $<0,05$ maka terdapat heteroskedastisitas.

Berdasarkan hasil uji heterokedastisitas dapat dilihat bahwa masing-masing variabel independen tidak signifikan secara statistik mempengaruhi variabel dependen nilai Absolut Residual (AbsRes). Semua variabel mempunyai probabilitas signifikansi $>0,05$, sehingga dapat disimpulkan model regresi tidak mengandung adanya heteroskedastisitas.

Setelah uji asumsi klasik terpenuhi, dilakukan pengujian hipotesis. Hipotesis dalam pelitian ini diuji dengan menggunakan model regresi linier berganda. Model regresi berganda digunakan untuk memecahkan rumusan masalah yang ada, yaitu untuk melihat pengaruh diantara dua variabel atau lebih. Variabel dependen pada penelitian ini adalah keberhasilan pengelolaan dana desa. Variabel independen pada penelitian ini, diantaranya: partisipasi masyarakat, penggunaan Siskeudes, kompetensi pendamping desa, dan komitmen pemerintah daerah.

Berdasarkan perhitungan regresi linear berganda pada tabel 5, maka didapatkan hasil persamaan regresi sebagai berikut:

$$
\begin{gathered}
Y=7,280+0,027 X_{1}+0,257 X_{2}+ \\
0,306 X_{3}+0,448 X_{4}+\varepsilon
\end{gathered}
$$

Selanjutnya dilakukan uji statistik $t$ yang menunjukkan seberapa besar pengaruh satu variabel independen secara indivdu dalam menjelaskan variasi dari variabel dependen. 
Tabel 5. Rekapitulasi Hasil Analisis Regresi Linier Berganda

\begin{tabular}{llccccc}
\hline & \multicolumn{2}{c}{$\begin{array}{c}\text { Unstandardized } \\
\text { Coefficients }\end{array}$} & $\begin{array}{c}\text { Standardized } \\
\text { Coefficients }\end{array}$ & & \\
\cline { 2 - 4 } Model & $B$ & Std. Error & Beta & $t$ & Sig. \\
\hline $1 \quad$ (Constant) & 7,280 & 1,763 & & 4,129 & 0,000 \\
& $\begin{array}{l}\text { Partisipasi Masyarakat } \\
\text { Penggunaan Siskeudes }\end{array}$ & 0,027 & 0,038 & 0,027 & 2,713 & 0,048 \\
$\quad \begin{array}{l}\text { Kompetensi Pendamping } \\
\text { Desa }\end{array}$ & 0,306 & 0,033 & 0,081 & 0,129 & 3,187 & 0,002 \\
$\quad \begin{array}{l}\text { Komitmen Pemerintah } \\
\text { Daerah }\end{array}$ & 0,448 & 0,050 & 0,429 & 8,974 & 0,000 \\
\hline
\end{tabular}

a. Dependent Variable: Keberhasilan Pengelolaan Dana Desa

Sumber: Data Diolah, 2018

Berdasarkan hasil uji statistik $\mathrm{t}$ yang telah dilakukan, maka dapat ditarik simpulan sebagai berikut yaitu pengujian hipotesis pertama $\left(\mathrm{H}_{1}\right)$ dapat dilihat pada tabel 5 bahwa nilai signifikansi variabel partisipasi masyarakat sebesar 0,048<0,05, maka dapat dinyatakan bahwa variabel $\mathrm{X}_{1}$ mempunyai pengaruh terhadap $Y$. Pengujian hipotesis kedua $\left(\mathrm{H}_{2}\right)$ dapat dilihat pada tabel 5 bahwa nilai signifikansi penggunaan Siskeudes sebesar 0,002 < 0,05, maka dapat dinyatakan bahwa variabel $\mathrm{X}_{2}$ mempunyai pengaruh terhadap Y. Pengujian hipotesis ketiga $\left(\mathrm{H}_{3}\right)$ dapat dilihat pada tabel 5 bahwa nilai signifikansi variabel kompetensi pendamping desa sebesar 0,000 < 0,05, maka dapat dinyatakan bahwa variabel $\mathrm{X}_{3}$ mempunyai pengaruh terhadap $Y$. Pengujian hipotesis keempat $\left(\mathrm{H}_{4}\right)$ dapat dilihat pada tabel 5 bahwa nilai signifikansi variabel komitmen pemerintah daerah sebesar $0,000<0,05$, maka dapat dinyatakan bahwa variabel $\mathrm{X}_{4}$ mempunyai pengaruh terhadap $\mathrm{Y}$.

Uji hipotesis selanjutnya yaitu uji koefisien determinasi, koefisien determinasi digunakan mengukur seberapa jauh kemampuan model dalam menjelaskan variasi variabel dependen.Koefisien determinasi pada penelitian ini, menggunakan nilai dari Adjusted $\mathrm{R}^{2}$. Dikarenakan nilai Adjusted $\mathrm{R}^{2}$ dapat naik atau turun apabila satu variabel ditambah kedalam model.

Berdasarkan data pada tabel 6, dapat dilihat bahwa nilai Adjusted $R$ Square sebesar 0,779 yang menunjukkan bahwa variasi variabel partisipasi masyarakat, penggunaan Siskeudes, kompetensi pendamping desa, dan komitmen pemerintah daerah hanya mampu menjelaskan $77,9 \%$ variasi variabel keberhasilan 
pengelolaan dana desa. Sisanya sebesar 22,1\% dipengaruhi oleh faktor lain di luar penelitian ini yang dapat mempengaruhi keberhasilan pengelolaan dana desa.

Tabel 6. Rekapitulasi Hasil Analisis Koefisien Determinasi

Model Summary

\begin{tabular}{ccccc}
\hline Model & $R$ & $R$ Square & $\begin{array}{c}\text { Adjusted } R \\
\text { Square }\end{array}$ & $\begin{array}{c}\text { Std. Error of the } \\
\text { Estimate }\end{array}$ \\
\hline 1 & $0,885^{\mathrm{a}}$ & 0,783 & 0,779 & 1,79256 \\
\hline
\end{tabular}

Sumber: Data Diolah, 2019

\section{Pembahasan}

Pengaruh Partisipasi Masyarakat Terhadap Keberhasilan Pengelolaan Dana Desa

Berdasarkan hasil uji statistik deskriptif, dapat dilihat bahwa variabel partisipasi masyarakat (X1) mempunyai skor minimum 20, skor maksimum 35 , skor rata-rata 28,46 dengan standar deviasi 3,751. Hal ini menunjukkan bahwa terjadi perbedaan nilai partisipasi masyarakat terhadap nilai rata-rata sebesar 3,751. Sementara itu, variabel keberhasilan pengelolaan dana desa (Y) mempunyai skor minimum 42, skor maksimum 60, skor rata-rata 52,71 dengan standar deviasi 3,816. Hal ini menunjukkan bahwa terjadi perbedaan nilai keberhasilan pengelolaan dana desa terhadap nilai rata-rata sebesar 3,816.Hasil analisis regresi linear berganda menunjukkan bahwa koefisien regresi partisipasi masyarakat sebesar 0,027 berarti bahwa apabila terdapat penambahan partisipasi masyarakat sebesar 1 satuan, maka keberhasilan pengelolaan dana desa akan meningkat sebesar 0,027 satuan. Hasil uji statistik $t$ menunjukkan bahwa nilai signifikansi variabel partisipasi masyarakat sebesar 0,048 $<0,05$, maka dapat dinyatakan bahwa variabel X1 mempunyai pengaruh terhadap $\mathrm{Y}$. Nilai $\mathrm{t}$ positif menunjukkan bahwa variabel $\mathrm{X} 1$ mempunyai hubungan yang searah dengan Y. Jadi dapat disimpulkan bahwa $\mathrm{H} 1$ diterima yaitu partisipasi masyarakat berpengaruh positif dan signifikan terhadap keberhasilan pengelolaan dana desa.

Secara teori, partisipasi masyarakat merupakan salah satu faktor yang mempengaruhi keberhasilan dari program pembangunan maupun pengembangan masyarakat pedesaan. Partisipasi masyarakat diperlukan untuk mewujudkan pembangunan desa yang sesuai dengan kebutuhan 
desa itu sendiri. Tanpa partisipasi masyarakat setiap kegiatan pembangunan akan gagal. Demikian juga halnya terkait dengan partisipasi masyarakat terhadap penggunaan dan pengelolaan dana desa, keterlibatan ini penting agar penggunaan dan pengelolaannya bisa lebih tepat sasaran dan manfaatnya akan lebih mengena dengan kepentingan riil dari masyarakat.

Partisipasi masyarakat sangat dibutuhkan untuk keberhasilan pembangunan di desa menuju kearah yang lebih baik, peran dan kinerja pemerintahan desa juga sangat diharapkan untuk dapat menjalankan tugas pokok memimpin dan mengkoordinasikan dalam melaksanakan urusan rumah tangga desa, melakukan pembinaan dan pembangunan masyarakat dan membina perekonomian desa. (Lomboh, 2015). Seperti yang dikatakan oleh Sekretaris Jenderal (Sekjen) Kementerian Desa, Pembangunan Daerah Tertinggal, dan Transmigrasi (Kemendes PDTT) bahwa pengelolaan dana desa dilakukan secara transparan dan bertanggungjawab. Pelibatan masyarakat dalam proses perencanaan, pelaksanaan, hingga pengawasan program-program pembangunan desa menjadi kunci keberhasilan pengelolaan dana desa.
Berdasarkan konsep yang ada dan pengujian yang telah dilakukan tampak bahwa partisipasi masyarakat dapat berpengaruh terhadap keberhasilan pengelolaan dana desa. Hasil penelitian menunjukkan bahwa partisipasi masyarakat memiliki hubungan searah terhadap keberhasilan pengelolaan dana desa. Hal ini berarti bahwa semakin tinggi tingkat partisipasi masyarakat, maka tingkat keberhasilan pengelolaan dana desa akan semakin tinggi pula. Hasil penelitian ini sejalan dengan penelitian sebelumnya yang dilakukan oleh Gameliel (2015) yang menyatakan bahwa partisipasi masyarakat berpengaruh positif dan signifikan terhadap akuntabilitas pengelolaan dana desa di Kabupaten Gorontalo.

\section{Pengaruh Penggunaan Siskeudes Terhadap Keberhasilan Pengelolaan Dana Desa}

Berdasarkan uji statistik deskriptif, dapat dilihat bahwa variabel penggunaan Siskeudes (X2) mempunyai skor minimum 18, skor maksimum 25, skor rata-rata 21,66 dengan standar deviasi 1,906 . Hal ini menunjukkan bahwa terjadi perbedaan nilai penggunaan Siskeudes terhadap nilai rata-rata sebesar 1,906. Sementara itu, variabel keberhasilan pengelolaan 
dana desa (Y) mempunyai skor minimum 42, skor maksimum 60, skor rata-rata 52,71 dengan standar deviasi 3,816. Hal ini menunjukkan bahwa terjadi perbedaan nilai keberhasilan pengelolaan dana desa terhadap nilai rata-rata sebesar 3,816.Hasil analisis regresi llinear berganda menunjukkan bahwa koefisien regresi penggunaan Siskeudes sebesar 0,257 berarti bahwa apabila terdapat penambahan penggunaan Siskeudes sebesar 1 satuan, maka keberhasilan pengelolaan dana desa akan meningkat sebesar 0,257 satuan. Hasil uji statistik $t$ menunjukkan bahwa nilai signifikansi nilai-nilai social sebesar $0,002<0,05$, maka dapat dinyatakan bahwa variabel X2 mempunyai pengaruh terhadap $\mathrm{Y}$. Nilai $t$ positif menunjukkan bahwa variabel X2 mempunyai hubungan yang searah dengan Y. Jadi dapat disimpulkan bahwa $\mathrm{H} 2$ diterima yaitu penggunaan Siskeudes berpengaruh positif dan signifikan terhadap keberhasilan pengelolaan dana desa.

Secara teori, pemberian dana ke desa yang begitu besar, jumlah pelaporan yang beragam dalam pengelolaan keuangan desa tentunya menuntut tanggung jawab yang besar pula oleh Aparat Pemerintah Desa. Oleh karena itu Pemerintah Desa harus bisa menerapkan prinsip akuntabilitas dalam pengelolaan keuangan desa, dimana semua akhir kegiatan penyelenggaraan pemerintahan desa harus dapat dipertanggungjawabkan kepada masyarakat desa sesuai dengan ketentuan sehingga terwujud tata kelola pemerintahan desa yang baik (Good Village Governance). Untuk dapat menerapkan prinsip akuntabilitas tersebut, diperlukan berbagai sumber daya dan sarana pendukung, diantaranya sumber daya manusia yang kompeten serta dukungan sarana teknologi informasi yang memadai dan dapat diandalkan.

Sistem Keuangan Desa
(Siskeudes) sangat diperlukan dalam pengelolaan keuangan pemerintahan desa. Keberadaannya membantu agar semua proses pembangunan, mulai dari perencanaan, pelaksanaan hingga evaluasi bisa dilaksanakan dengan baik. Dengan adanya siskeudes ini akan membantu pengelolaan keuangan dana desa secara transparan dan akuntabel, dengan penggunaan sistem keuangan desa yang baik akan mempermudah dan mempercepat dalam hal pencairan dana desa untuk periode selanjutnya karena sudah melaporkan realisasi periode sebelumnya secara tepat waktu. Dengan begitu sistem keuangan desa sangat berperan penting dalam hal 
keberhasilan pengelolaan dana desa. Berdasarkan konsep yang ada dan pengujian yang telah dilakukan tampak bahwa penggunaan Siskeudes dapat berpengaruh terhadap keberhasilan pengelolaan dana desa. Hasil penelitian menunjukkan bahwa penggunaan Siskeudes memiliki hubungan searah dengan keberhasilan pengelolaan dana desa. Hal ini berarti bahwa penggunaan Siskeudes dapat meningkatlan keberhasilan pengelolaan dana desa.

Pengaruh Kompetensi Pendamping Desa Terhadap Keberhasilan Pengelolaan Dana Desa

Berdasarkan hasil uji statistik deskriptif, dapat dilihat bahwa variabel kompetensi pendamping desa (X3) mempunyai skor minimum 50, skor maksimum 70, skor rata-rata 61,77 dengan standar deviasi 5,561. Hal ini menunjukkan bahwa terjadi perbedaan nilai kompetensi pendamping desa terhadap nilai ratarata sebesar 5,561. Sementara itu, variabel keberhasilan pengelolaan dana desa (Y) mempunyai skor minimum 42, skor maksimum 60, skor rata-rata 52,71 dengan standar deviasi 3,816. Hal ini menunjukkan bahwa terjadi perbedaan nilai keberhasilan pengelolaan dana desa terhadap nilai rata-rata sebesar
3,816.Hasil analisis regresi linear berganda menunjukkan bahwa koefisien regresi kompetensi pendamping desa sebesar 0,306 berarti bahwa apabila terdapat penambahan kompetensi pendamping desa sebesar 1 satuan, maka keberhasilan pengelolaan dana desa akan meningkat sebesar 0,306 satuan. Hasil uji statistik $t$ menunjukkan bahwa nilai signifikansi variabel kompetensi pendamping desa sebesar $0,000<0,05$, maka dapat dinyatakan bahwa variabel X3 mempunyai pengaruh terhadap $Y$. Nilai $t$ positif menunjukkan bahwa variabel X3 mempunyai hubungan yang searah dengan $Y$. Jadi dapat disimpulkan bahwa H3 diterima yaitu kompetensi pendamping desa berpengaruh positif dan signifikan terhadap keberhasilan pengelolaan dana desa.

Secara teori, kompetensi dapat diartikan sebagai kemampuan seseorang dalam menghadapi situasi dan keadaan di dalam pekerjaannya. Kompetensi seseorang dapat dilihat dari tingkat kreativitas yang dimilikinya serta inovasi-inovasi yang diciptakan dan kemampuannya dalam menyelesaikan suatu masalah. Menurut Zirman mengungkapkan bahwa kompetensi merupakan kombinasi pengetahuan dan keterampilan yang relevan 
dengan pekerjaaan. Kompetensi adalah kapasitas untuk menangaani suatu pekerjaan atau tugas berdasarkan suatu standar yang telah ditetapkan (Rudana, 2005).

Berdasarkan konsep yang ada dan hasil pengujian yang telah dilakukan tampak bahwa kompetensi pendamping desa berpengaruh terhadap pengelolaan dana desa. Hasil penelitian Pratama (2017) menunjukkan bahwa kinerja pendamping desa dengan melakukan pendekatan-pendekatan social seperti lebih sering berkomunikasi dengan desa dan masyarakatnya serta bertatap muka langsung sehingga akan terjalin ikatan yang baik, dan lain sebagainya berpengaruh terhadap upaya membangun kemandirian desa. Hasil penelitia Pahlevi (2017) juga menyatakan bahwa pendamping desa memiliki pengaruh yang signifikan terhadap keberhasilan pengelolaan dana desa, pengaruh ini dapat dibuktikan dengan pernyataan bahwa banyaknya faktor penghambat dalam pelaksanaan kewenangan pendamping desa yaitu kurangnya partisipasi dari masyarakat desa, ketersediaan fasilitas yang belum memadai, dan kurangnya jumlah sumber daya manusia sebagai pendamping desa.
Pengaruh Komitmen Pemerintah Daerah Terhadap Keberhasilan Pengelolaan Dana Desa

Berdasarkan hasil uji statistik deskriptif, dapat dilihat bahwa variabel komitmen pemerintah daerah (X4) mempunyai skor minimum 38, skor maksimum 50, skor rata-rata 45,05 dengan standar deviasi 3,654. Hal ini menunjukkan bahwa terjadi perbedaan nilai komitmen pemerintah daerah terhadap nilai rata-rata sebesar 3,654. Sementara itu, variabel keberhasilan pengelolaan dana desa (Y) mempunyai skor minimum 42, skor maksimum 60, skor rata-rata 52,71 dengan standar deviasi 3,816. Hal ini menunjukkan bahwa terjadi perbedaan nilai keberhasilan pengelolaan dana desa terhadap nilai rata-rata sebesar 3,816.Hasil analisis regresi linear berganda menunjukkan bahwa koefisien regresi komitmen pemerintah daerah sebesar 0,448 berarti bahwa apabila terdapat penambahan komitmen pemerintah daerah sebesar 1 satuan, maka keberhasilan pengelolaan dana desa akan meningkat sebesar 0,448 satuan. Hasil uji statistik $t$ menunjukkan bahwa nilai signifikansi variabel komitmen pemerintah daerah sebesar $0,000<0,05$, maka dapat dinyatakan bahwa variabel X4 mempunyai pengaruh terhadap $\mathrm{Y}$. 
Nilai $t$ positif menunjukkan bahwa variabel X4 mempunyai hubungan yang searah dengan Y. Jadi dapat disimpulkan bahwa $\mathrm{H} 4$ diterima yaitu komitmen pemerintah daerah berpengaruh positif dan signifikan terhadap keberhasilan pengelolaan dana desa.

Secara teori, semangat UndangUndang Desa memberi ruang kewenangan bagi desa untuk menentukan arah pembangunan desa kedepan, sehingga desa tidak lagi menjadi objek pembangunan melainkan sebagai pelaku pembangunan itu sendiri. Semangat Undang-undang Desa merupakan wujud dari komitmen pemerintah mendorong otonomi desa. Hajatan undang-undang ini salah satunya adalah mendorong desa menjadi, lebih luas lagi bagaimana desa menjadi bertenaga secara sosial, gotong royong, rukun dan saling menghormati, berdaulat secara politik mampu dan berani mengambil keputusan, berdaya secara ekonomi (dengan mengembangkan asset-aset lokal), dan bermartabat secara budaya. Namun, komitmen tidak hanya dari pemerintah pusat, melainkan dari pemerintah daerah dan lembaga lainnya yang terkait dengan pengelolaan dana desa. Wujud komitmen pemerintah daerah dalam pengelolaan dana desa dapat berupa pemberian pembinaan, pelatihan serta pengawasan dalam hal penggunaan dana desa supaya tepat sasaran.

Berdasarkan konsep yang ada dan pengujian yang dilakukan tampak bahwa komitmen pemerintah daerah dapat mempengaruhi keberhasilan pengeloaan dana desa. Hasil penelitian menunjukkan bahwa komitmen pemerintah daerah memiliki hubungan searah dengan pengelolaan dana desa. Hal ini menunjukkan bahwa semakin tinggi tingkat komitmen pemerintah daerah, maka keberhasilan pengelolaan dana desa akan semakin tinggi pula. Hasil penelitian ini sejalan dengan penelitian terdahulu yang dilakukan oleh Gameliel (2015) yang menunjukkan hasil bahwa komitmen organisasi pemerintah desa berpengaruh positif dan signifikan terhadap akuntabilitas pengelolaan dana desa di Kabupaten Gorontalo.

\section{KESIMPULAN, IMPLIKASI DAN KETERBATASAN PENELITIAN}

\section{Kesimpulan}

Berdasarkan penelitian yang telah dilakukan mengenai variabel partisipasi masyarakat, penggunaan sistem keuangan desa, kompetensi pendamping desa, serta komitmen pemerintah daerah terhadap keberhasilan pengelolaan dana desa 
maka dapat disimpulkan sebagai berikut: (1) partisipasi masyarakat berpengaruh secara positif dan signifikan terhadap keberhasilan pengelolaan dana desa, penggunaan Siskeudes berpengaruh secara positif dan signifikan terhadap keberhasilan pengelolaan dana desa, (3) kompetensi pendamping desa berpengaruh secara positif dan signifikan terhadap keberhasilan pengelolaan dana desa, dan (4) komitmen pemerintah daerah berpengaruh secara positif dan signifikan terhadap keberhasilan pengelolaan dana desa.

\section{Saran}

Bagi pemerintah desa, untuk meningkatkan partisipasi masyarakat dan penggunaan Siskeudes dalam meningkatkan keberhasilan pengelolaan dana desa serta pemerintah daerah tetap pada komitmen untuk meningkatkan keberhasilan pengelolaan dana desa, serta pendamping desa diharapkan dapat meningkatkan kompetensinya, sehingga pengelolaan dana desa akan lebih optimal dan menunjukkan keberhasilan yang maksimal.

Bagi Peneliti Selanjutnya, jika tertarik untuk melakukan penelitian yang sama, diharapkan untuk lebih mengembangkan variabel yang diteliti sebagai variabel pendukung yang mempengaruhi keberhasilan pengelolaan dana desa dan juga menambah indikator maupun daftar pertanyaan yang akan digunakan agar hasil penelitian yang diperoleh dapat lebih baik. Selain itu, diharapkan pula dapat memperluas responden dan ruang lingkup penelitian agar lebih dapat digeneralisasi.

\section{REFERENSI}

Diaputra, Rizka. 2018. Mendes PDTT: Tak Ada Desa Tertinggal di Bali Berkat Dana Desa. Diakses dari https://news.okezone.com/rea d/2018/05/07/337/1895459/ mendes-pdtt-tak-ada-desatertinggal-di-bali-berkat-danadesa

Gameliel. 2015. Pengaruh Kompetensi Aparat Pengelolaan Dana Desa, Komitmen Organisasi Pemerintah Desa,da Partisipasi Masyarakat Terhadap Akuntabilitas Pengelolaan Dana Desa Di kabupaten Gorontalo. Skripsi.Universitas Negeri Gorontalo

Ghozali. 2011. Aplikasi Analisis Multivariat Dengan Program SPSS. Semarang: BP Undip.

Lomboh, Arthur T. 2015. Partisipasi Masyarakat Dalam Pembangunan Di Desa Lesabe Kecamatan Tabukan Selatan Kabupaten Kepulauan Sangihe. Diunduh dari https://media.neliti.com/media /publications/1091-IDpartisipasi-masyarakat-dalampembangunan-di-desa-lesabekecamatan-tabukan-selata.pdf 
Pahlevi, Reza. 2017. Kewenangan Pendamping Desa Dalam Rangka Penyelenggaraan Pemerintah Desa. Skripsi. Universitas Lampung

Parwati, Kadek Juni, I Gusti Ayu Purnamawati, Made Aristia Prayudi. 2017.Pengaruh

Kompetensi Pendamping Desa, Sistem Pengendalian Internal Pemerintah Desa, dan Komitmen Aparatur Desa Terhadap Keberhasilan Pengelolaan Dana Desa Di Kabupaten Buleleng. Jurnal Ilmiah Mahasiswa Akuntansi, Vol. 8, No. 2

Pratama. 2017. Analisis Kinerja Pendamping Desa Dalam Upaya Membangun Kemandirian Desa. Skripsi. Universitas lampung

Rudana, N. 2005. Pengaruh Komptensi Aparatur PEMDA dan Komunikasi Interpersonal terhadap Kualitas Pelayanan Publik di Kantor Kabupaten Gianyar. Skripsi. Universitas Diponegoro.

Saputra, Komang Adi Kurniawan, Anantawikrama Tungga Atmadja, dan Made Koni
Koswara. 2018. The Influence of Village Conflict, Village Apparatus Ability, Village Facilitator Competency And Commitment of Local Government On The Success Of Budget Management. Diunduh dari https://www.abacademies.org/ articles/the-influence-ofvillage-conflict-villageapparatus-ability-villagefacilitator-competency-15282635-22-1-102.pdf

Yujana, Lalu Hendry. 2017. Ikut Mengawal Dana Desa. Media Keuangan: Transparansi Informasi Kebijakan Fiskal, Volume XII, No.116, Halaman 20-24.

Zirman. 2010. Pengaruh Kompetensi Aparatur Pemerintah Daerah, Penerapan Akuntabilitas Keuangan, Motivasi Kerja dan Ketaatan Pada Peraturan Perundangan terhadap Akuntabilitas Kinerja Instansi Pemerintah. Jurnal Ekonomi. Vol.18, No 1 